\title{
The $A M H$ genotype (rs10407022 T>G) is associated with circulating AMH levels in boys, but not in girls
}

\author{
Iben Katinka Greiber, Casper P Hagen, Alexander Siegfried Busch, Mikkel Grunnet Mieritz, Lise Aksglæde, \\ Katharina Main, Kristian Almstrup and Anders Juul \\ Department of Growth and Reproduction, EDMaRC, Rigshospitalet, University of Copenhagen, Copenhagen, Denmark \\ Correspondence should be addressed to I K Greiber: ibengreiber@hotmail.com
}

\section{Abstract}

Objective: Fetal anti-Müllerian hormone (AMH) is responsible for normal male sexual differentiation, and circulating $\mathrm{AMH}$ is used as a marker of testicular tissue in newborns with disorders of sex development. Little is known about the mechanism of action in postnatal life. A recent genome wide association study (GWAS) reported genetic variation of $\mathrm{AMH}$ affecting $\mathrm{AMH}$ levels in young men. This study investigated the effect of genetic variation of AMH and AMH type II receptor (AMHR2) (AMHrs10407022 T>G and $A M H R 2$ rs11170547 C>T) on circulating reproductive hormone levels and

\section{Key Words}

- anti-Mullerian hormone

- anti-Mullerian hormone receptor

- single-nucleotide polymorphism

- puberty pubertal onset in boys and girls.

Design and methods: This study is a combined longitudinal and cross-sectional study in healthy Danish boys and girls from the general population. We included 658 boys aged 5.8-19.8 years and 320 girls aged 5.6-16.5 years. The main outcome measures were genotyping of $A M H$ and $A M H R 2$, pubertal staging and serum levels of reproductive hormones.

Results: $A M H r s 10407022 T>G$ was associated with higher serum levels of $A M H$ in prepubertal boys (TT: $575 \mathrm{pmol} / \mathrm{L}$ vs TG: $633 \mathrm{pmol} / \mathrm{L}$ vs GG: $837 \mathrm{pmol} / \mathrm{L}, P=0.002$ ) and adolescents (TT: $44 \mathrm{pmol} / \mathrm{L}$ vs TG: $58 \mathrm{pmol} / \mathrm{L}$ vs $\mathrm{GG}: 79 \mathrm{pmol} / \mathrm{L}, P<0.001)$. Adolescent boys carrying the genetic variation also had lower levels of LH (TT: $3.0 \mathrm{IU} / \mathrm{L}$ vs TG: $2.8 \mathrm{IU} / \mathrm{L}$ vs GG: $1.8 \mathrm{IU} / \mathrm{L}, P=0.012$ ). Hormone levels in girls and pubertal onset in either sex did not seem to be profoundly affected by the genotypes.

Conclusion: Our findings support recent GWAS results in young adults and expand our understanding of genetic variation affecting $\mathrm{AMH}$ levels even in boys prior to the pubertal decline of circulating $\mathrm{AMH}$.

\section{Introduction}

Anti-Müllerian hormone (AMH) is produced by immature Sertoli cells in the male and in granulosa cells in preantral and small antral follicles in the female $(1,2)$. AMH is a glycoprotein hormone belonging to the TGF- $\beta$ superfamily (3) and is encoded by the $A M H$ gene. AMH binds to the specific AMH type II receptor (AMHR2) (4).

http://www.endocrineconnections.org https://doi.org/10.1530/EC-17-0299
In the male fetus, $\mathrm{AMH}$ is essential for regression of the Müllerian ducts $(5,6)$. In a 46,XY fetus, mutations of $A M H$ or $A M H R 2$ cause persistent Müllerian duct syndrome (PMDS) often including bilateral cryptorchidism but otherwise normal virilization of external genitalia (7). In postnatal life, serum levels of $\mathrm{AMH}$ are high during

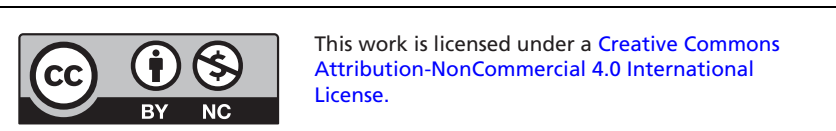


childhood but decline rapidly during puberty when the Sertoli cells differentiate and start to express androgen receptors $(8,9)$. The function of $\mathrm{AMH}$ in adult men is not known. Circulating AMH varies widely between male individuals at levels comparable with levels in young adult females (10). No strong associations between serum AMH levels, and reproductive parameters have been reported in adult men (11). However, AMH concentrations in seminal fluid have been positively associated with sperm motility and spermatogenesis $(12,13,14)$.

In women, AMH seems to be a gatekeeper of estradiol and inhibin B production by inhibition of FSH-induced follicle growth (15) and aromatase activity in granulosa cells $(16,17,18)$. Circulating levels of AMH reflect the number of antral follicles as well as the number of resting primordial follicles (19). Thus, age-specific AMH levels appear to predict age at menopause (20). Healthy girls tend to maintain their individual AMH levels throughout childhood and puberty with minor fluctuations at the onset of puberty (21).

The biological actions of $\mathrm{AMH}$ depend on the individual $\mathrm{AMH}$ production and AMHR2 sensitivity. The non-synonymous single-nucleotide polymorphism (SNP) rs10407022 (AMH rs10407022 T>G) found in the coding region of $A M H$ causes amino acid substitution (Ile ${ }^{49}$ Ser), and minor allele carriers seem to have impaired AMH signaling/function (22). The SNP is associated with higher follicular phase estradiol levels in normo-ovulatory women and thereby supporting the notion of $\mathrm{AMH}$ regulating FSH-sensitivity in the ovary (23).

The non-coding rs11170547 SNP (AMHR2 rs11170547 $\mathrm{C}>\mathrm{T}$ ) is located in a putative enhancer of the gene encoding AMHR2 (24). Thus, a reduced expression of AMHR2 on cell surfaces is expected in minor allele carriers. Accordingly, rs11170547 $\mathrm{T}$ is positively associated with circulating estradiol levels in adult women (22). Interaction between $A M H$ rs10407022 $\mathrm{T}>\mathrm{G}$ and $A M H R 2$ rs11170547 $\mathrm{C}>\mathrm{T}$ is associated with age at menopause (25).

In a genome wide association study (GWAS) of British adolescents, a considerable part of inter-individual variation of circulating $\mathrm{AMH}$ levels was explained by genetic variation of $A M H$ in young men but not in women (26). The present study is to our knowledge the first to assess the effect of genetic variation of AMH signaling (AMH rs10407022 T>G and AMHR2 rs11170547 C>T) on circulating hormone levels in boys and girls during pubertal development.

Our findings support recent GWAS results in young adults and expand our understanding of genetic variation

$$
\text { http://www.endocrineconnections.org }
$$

affecting AMH levels even in boys prior to the pubertal decline of circulating AMH.

\section{Subjects and methods}

\section{Healthy boys and girls}

Participants were recruited from The Copenhagen Puberty Study $(27,28)$, a population-based combined crosssectional and longitudinal cohort study of healthy Danish children and adolescents. The study was conducted at ten schools in the Copenhagen area, 2006-2014. All pupils were invited, 3102 girls and 3101 boys of whom 35\% girls and $25 \%$ boys chose to participate.

We included all boys (658) and girls (320) with available DNA analyses on $A M H$ rs10407022 T>G and AMHR2 rs11170547 $\mathrm{C}>\mathrm{T}$ as well as Tanner stage, and serum levels of AMH or inhibin B. No children had a history of endocrine, gynecological or cerebral illness.

Cross-sectional part of the study: 558 boys and 236 girls, median (range) age; boys: 11.6 (6.1-19.8) and girls: 10.7 (6.0-14.9). Longitudinal part of the study, 84 girls and 100 boys from two of the included schools were examined twice a year. Median (range) age at baseline; girls: 9.2 (5.6-12.9) years and boys: 9.4 (5.8-15.6) years. The children were followed for an average of 4.6 years $(0.5-7.6)$ for the girls and 5.5 (0.4-7.6) for the boys.

We have previously described reproductive hormone levels (21) and genotypes (FSH and FSHR) in the same cohorts (29). In the present study, we report novel data concerning AMH rs10407022 T>G and AMHR2 rs11170547 $\mathrm{C}>\mathrm{T}$, and their associations with circulating reproductive hormone levels.

Blood samples were drawn and a thorough clinical examination was performed in all participating children at every visit, including Tanner staging of breast (B1B5) and genital development (G1-G5) in girls and boys, respectively (30). The total or median (range) number of blood samples varied between gender and study design: Girls, cross-sectional part 236, longitudinal part 8 (2-14) per girl; boys, cross-sectional part 558, longitudinal part 9 (2-14) per boy.

The total number of children and blood samples available for hormone analyses: AMH (320 girls: 931 samples; 658 boys: 1408), FSH (318 girls: 929; 658 boys: 1406), LH (318 girls: 929; 658 boys: 1406), inhibin B (316 girls: 910; 658 boys: 1405), estradiol (318 girls: 920; 658 boys: 1405$)$ and testosterone (319 girls: 930; 658 boys: 1405$)$. 


\section{Genotyping}

Peripheral blood (EDTA-preserved) was used for isolation of genomic DNA using the QuickGene-810 Nucleic Acid Isolation System (Fujifilm, Life Science Products, Tokyo, Japan) and quantified on a NanoDrop ND-1000 spectrophotometer (Saveen Werner, Limhamn, Sweden).

The SNPs were analyzed using KASP SNP genotyping assays (LGC Genomics, Hoddesdon, UK), which facilitates bi-allelic discrimination through a competitive PCR and incorporation of a fluorescent resonance energy transfer quencher cassette. KASP genotyping assays were designed by LGC Genomics toward the following sequences: rs10407022, CTCCAGGCA[T/G]CCCACAAGAGC and rs11170547, GTTCTCCCTTTCAC[C/T]TACTAACACTAATTTG. A standard touch-down PCR program, as advised from the manufactures, was used to discriminate alleles. The annealing temperature was decreased by $0.6^{\circ} \mathrm{C}$ in 10 cycles from $61^{\circ} \mathrm{C}$ to $55^{\circ} \mathrm{C}$ for $A M H R 2$ rs11170547 $\mathrm{C}>\mathrm{T}$ and from $68^{\circ} \mathrm{C}$ to $62^{\circ} \mathrm{C}$ for $A M H$ rs $10407022 \mathrm{~T}>\mathrm{G}$.

\section{Reproductive hormone assays}

All blood samples were drawn between 8:00 h and 13:00 h from an antecubital vein, clotted and centrifuged, and serum was stored at $-20^{\circ} \mathrm{C}$ until hormone analyses were performed. Blood samples were analyzed after maximum 8 years of storage in a freezer at $-20^{\circ} \mathrm{C}$. All samples were analyzed in the same laboratory blinded for the technician for age and pubertal stage.

Serum AMH levels were determined using the Beckman Coulter enzyme immunometric assay (Immunotech, Beckman Coulter, Marseilles, France) with a detection limit of $2.0 \mathrm{pmol} / \mathrm{L}$. The intra- and inter-assay coefficients of variation (CVs) were less than $7.8 \%$ and $10.8 \%$, respectively. Serum levels of FSH and LH were measured by time-resolved immunofluorometric assays (Delfia; PerkinElmer) with detection limits of 0.06 and $0.05 \mathrm{IU} / \mathrm{L}$, respectively. Intra-assay and inter-assay CVs were less than $5 \%$. Serum concentrations of inhibin B were measured using the Beckman Coulter GenII assay with a detection limit of $3 \mathrm{pg} / \mathrm{mL}$ and inter-assay CV $<11 \%$. Serum estradiol was measured by radioimmunoassay (Pantex, Santa Monica, CA, USA), detection limit $18 \mathrm{pmol} / \mathrm{L}$ and intra- and inter-assay CVs were $<8$ and $13 \%$, respectively. Testosterone was quantified using a newly developed and validated TurboFlow-liquid chromatography-tandem mass spectrometry (LC-MS/MS) method (31). Detection limit was $0.10 \mathrm{nmol} / \mathrm{L}$, and relative standard deviation for the

http://www.endocrineconnections.org https://doi.org/10.1530/EC-17-0299

C 2018 The authors Published by Bioscientifica Ltd quality control sample at the low and high concentration level was $10.0 \%$ and $5.7 \%$, respectively. Hormone levels below the detection limit were assigned the value of 0.5 times the detection limit.

\section{Statistical analyses}

To evaluate if genotypes affected hormone levels as puberty progressed, longitudinal hormone levels stratified for genotypes were visualized according to age.

Our study contains data from the longitudinal part of The Copenhagen Puberty study ( $n=84$ girls and 100 boys). The raw dataset of each individual contains data collected in several examinations as puberty progressed. To evaluate the effect of SNPs on reproductive hormone levels, observations were grouped according to Tanner stage for each individual. To obtain sufficient group sizes for analyses, we formed subgroups according to merged Tanner stages as follows: Prepubertal girls: B1 and boys: G1; mid-pubertal girls: B2+B3 and boys: G2+G3; late pubertal girls: B4+B5 and boys: G4+G5 boys. If multiple observations within a specific Tanner subgroup were available from a given individual, a mean value was calculated. This mean value was introduced into the model and used as the single-occasion observations of the cross-sectional part of the study when performing statistical analyses. No girl contributed with more than one observation per statistical analysis.

Associations between genotypes (AMH rs10407022 $\mathrm{T}>\mathrm{G}$ and AMHR2 rs11170547 C>T) and circulating hormone levels were evaluated $(A M H$ rs10407022 TT vs TG vs GG and $A M H R 2$ rs11170547 CC vs CT vs TT) using the Kruskal-Wallis test. A $P$ value $\leq 0.05$ was considered statistically significant.

To determine if the genotypes influenced the onset of puberty (B2 or G2), we performed probit analyses (29).

\section{Ethical considerations}

The Copenhagen Puberty Study (ClinicalTrials.gov ID: NCT01411527) was carried out in accordance with the Second Helsinki Declaration and in accordance with the protocols approved by the scientific ethical committee at The Capital Region of Denmark (KF 01 284; V200.1996/90, KF 01 030/97/KF 01276357/H-12009-074) as well as the Danish Data Protection Agency (2010-41-5042). All children and parents received written information, and informed consent was obtained from all participants.

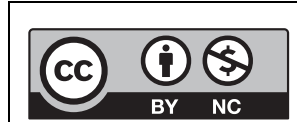

This work is licensed under a Creative Commons Attribution-NonCommercial 4.0 International License. 


\section{Results}

The children and adolescents had the following allele distributions: $A M H$ rs10407022 T>G (TT 684, TG 263, GG 24, minor allele frequency (MAF) 16\%) and AMHR2 rs11170547 C>T (CC 777, CT 188, TT 12, MAF 11\%). Distributions were consistent with Hardy-Weinberg equilibrium (Pearson's $\chi^{2}=0.05, P=0.830$ and $\chi^{2}=0.03$, $P=0.860$, respectively).

\section{Boys}

Boys carrying $A M H$ rs $10407022 \mathrm{G}$ had higher serum levels of AMH prior to - as well as after - the pubertal decline of AMH levels; prepubertal boys (G1); Median (Range) AMH TT: 575 (120-1883) pmol/L vs TG: 633 (66-2075) pmol/L vs GG: 837 (363-1468) pmol/L, $P=0.002$ and adolescents (G4+G5): TT: 44 (13-159) pmol/L vs TG: 58 (13-631) pmol/L vs GG 79 (50-119) pmol/L, $P<0.001$ (Fig. 1 and Supplementary Table 1 , see section on supplementary data given at the end of this article).

Adolescent boys carrying AMH rs10407022 G had lower serum levels of LH (G4+5): LH TT $3.0(0.4-9.3) \mathrm{IU} / \mathrm{L}$ vs TG $2.8(1.0-7.3) \mathrm{IU} / \mathrm{L}$ vs GG $1.8(0.6-3.6) \mathrm{IU} / \mathrm{L}, P=0.012$. No associations with FSH, inhibin B, testosterone or estradiol, respectively, were found (Supplementary Table 1).

We found a weak association between AMHR2 rs11170547 $\mathrm{C}>\mathrm{T}$ and lower serum levels of $\mathrm{AMH}$ in the mid-pubertal boys (G2+3): Median (Range) CC: 232 (20-1580) pmol/L vs CT: 150 (36-1086) pmol/L vs TT: 62 (49-75) $\mathrm{pmol} / \mathrm{L}, P=0.047$. AMHR2 rs $11170547 \mathrm{C}>\mathrm{T}$ was not systematically associated with any other of the circulating reproductive hormone levels (Supplementary Table 1).

\section{Girls}

Adolescent carriers of $A M H$ rs10407022 G had lower serum levels of estradiol (B4+5): TT 171 (31-681) pmol/L vs TG 174 (56-420) pmol/L vs GG 78 (37-113) pmol/L, $P=0.048$. This was mirrored by a nearly significant association with higher $\mathrm{LH}$ and lower testosterone in B4+5. No associations between $A M H \mathrm{rs} 10407022 \mathrm{~T}>\mathrm{G}$ and circulating levels of AMH, FSH or inhibin B, respectively, were found (Supplementary Table 1).

AMHR2 rs11170547 C>T was associated with lower serum estradiol levels in adolescent (B4+5) girls; CC 153 (31-562) pmol/L vs CT 194 (32-681) pmol/L vs TT 160 (121-198) $\mathrm{pmol} / \mathrm{L}, P=0.037$.

No associations between AMHR2 $\mathrm{rs} 11170547 \mathrm{C}>\mathrm{T}$ and $\mathrm{AMH}$, inhibin B, FSH, LH or testosterone, respectively, were found (Supplementary Table 1).

$$
\begin{aligned}
& \text { http://www.endocrineconnections.org } \\
& \text { https://doi.org/10.1530/EC-17-0299 }
\end{aligned}
$$
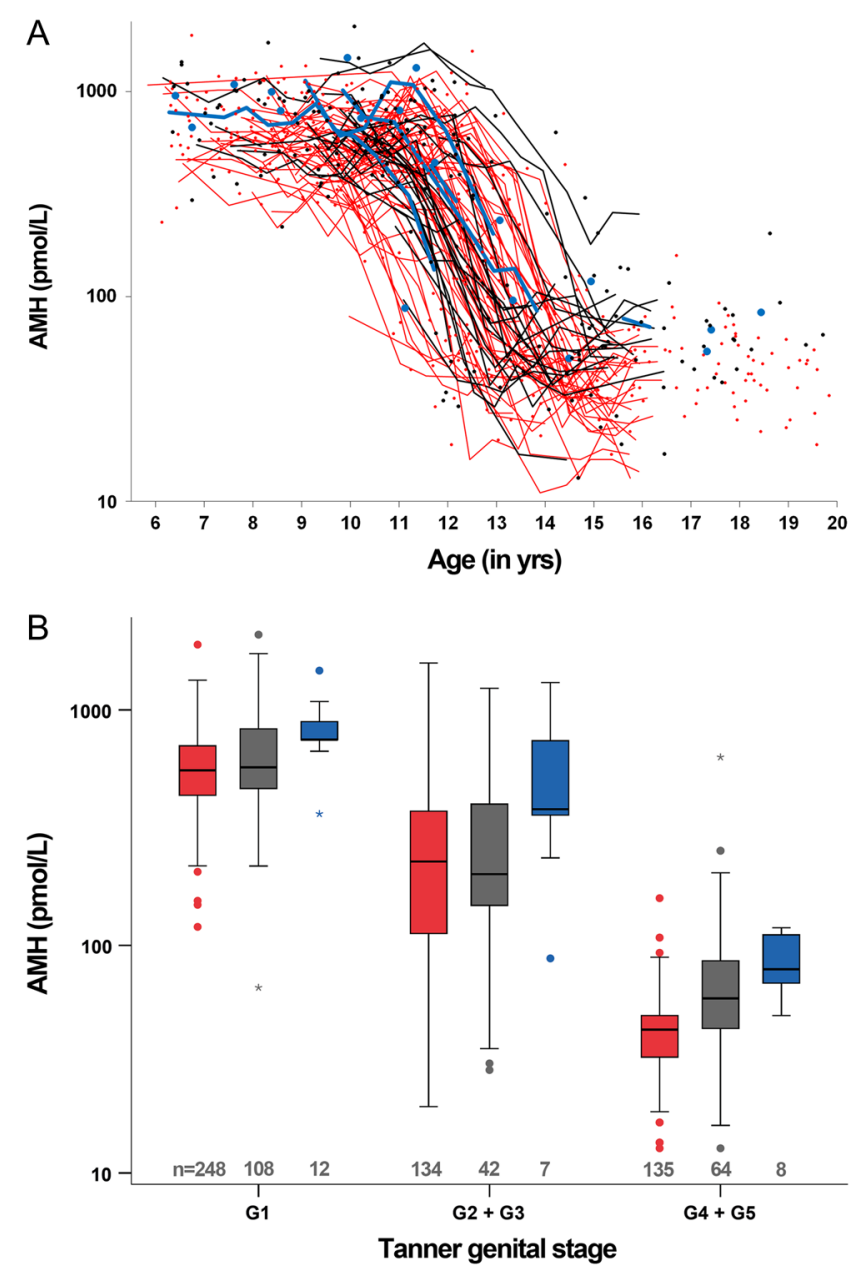

Figure 1

Boys. (A) Serum AMH levels according to age stratified by $A M H$ rs10407022 T>G, TT red; TG black; GG blue. (B) Serum AMH levels according to Tanner subgroups stratified by $A M H$ rs $10407022 \mathrm{~T}>\mathrm{G}$, TT red; TG black; GG blue. If multiple observations within a specific Tanner subgroup were available for the same boy, a mean value was calculated. In the boxplots medians are marked by thick black lines; boxes contain $50 \%$ of the distribution. Whiskers mark 2.5 th-97.5th percentile.

\section{Age at pubertal onset}

Neither genotype affected age at pubertal onset in boys nor girls; i.e. boys: mean age at testis volume $\geq 4 \mathrm{~mL}$ (95\% CI): $A M H$ rs10407022 TT 11.8 (11.6-11.9) years vs TG $11.8(11.6-12.1)$ years vs GG $11.4(10.7-12.1)$ years, $P=0.670$; AMHR2 rs11170547 CC 11.8 (11.6-11.9) years vs CT $11.9(11.6-12.2)$ years vs TT $11.1(9.7-12.5)$ years, $P=0.786$; girls: mean age at thelarche $(95 \% \mathrm{CI})$ : $A M H$ rs10407022 TT $10.0(9.8-10.2)$ years vs TG 9.9 (9.5-10.3) years vs GG $10.0(8.7-11.3)$ years, $P=0.554$; AMHR2 rs11170547 CC $10.0(9.8-10.3)$ years vs CT 9.7 (9.2-10.2) years vs TT $9.7(8.0-11.5)$ years, $P=0.183$ (data not shown).

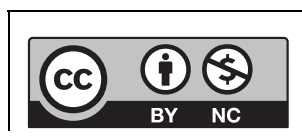

This work is licensed under a Creative Commons Attribution-NonCommercial 4.0 International License. 


\section{Discussion}

This is the first study to evaluate the effect of genetic variation affecting $\mathrm{AMH}$ signaling on reproductive hormones in healthy children before and during puberty. The genetic variation of $A M H(A M H$ rs10407022 T>G) was associated with serum levels of AMH in boys, but not in girls.

\section{Males}

We observed a significant effect of the selected SNP in the gene encoding $A M H$ on circulating AMH levels. The minor allele, $A M H$ rs10407022 G, was strongly associated with higher AMH levels in prepubertal (G1) and adolescent boys (G4+G5). Individual AMH levels are relatively stable in prepubertal boys and adolescents (8). However, we speculate that any genetic effect in the mid-pubertal boys (G2+G3) may have been blunted by the drastic pubertal decrease of serum AMH level (8) resulting in a greater variation of AMH levels depending on the specific timing of examination during pubertal onset. This wide dispersion of AMH levels in mid-pubertal boys may have been aggravated by the merging of Tanner stages (i.e. boys of G2+G3 treated as one group), which was necessary to perform reliable statistical analyses. There is a risk that the extreme decline of AMH is also responsible for the weak association observed in the mid-pubertal boys $(\mathrm{G} 2+3)$ between the AMHR2 rs11170547 $\mathrm{C}>\mathrm{T}$ minor alleles and lower circulating AMH levels. We would expect the reverse association indicating compensatory increased levels of AMH due to impaired signaling through the receptor.

In the present study, the effect on AMH levels in adolescence was not caused by an effect on age at pubertal onset. In support of our findings, a recent GWAS study of 1360 male and 1455 female British adolescents described that three SNPs in and around the $A M H$ gene had a strong influence on circulating AMH levels in males but not in females (26). Our findings add novel information on the impact of genetic variation in AMH signaling on circulating AMH levels in childhood and puberty.

The biological importance of the postnatal secretion of AMH and its large inter-individual variation of serum levels is still unknown. During the mid-childhood quiescence of the hypothalamic-pituitary-gonadal (HPG) axis, high AMH is a marker of testicular tissue (32). Low levels of AMH can be found in boys with bilateral cryptorchidism due to Sertoli cell dysfunction (33). In patients with Klinefelter syndrome (47,XXY), AMH declines to sub-normal levels simultaneously with

$$
\text { http://www.endocrineconnections.org }
$$

the pubertal hyalinization of seminiferous tubules (34). Thus, healthy adolescents with AMH levels in the low part of the normal range may have compromised Sertoli cell function. However, studies on semen from healthy males and patients have not showed associations between circulating AMH and reproductive parameters $(11,35) . A M H$ rs10407022 $\mathrm{G}$ was associated with lower levels of LH in the adolescent boys. This is in line with our previous report on an association between circulating AMH and LH in boys from the same cohort (8). Our present genetic findings suggest that AMH regulates LH levels. Whether regulation is exceeded directly on the hypothalamic-pituitary level (36) or a result of secondary effect of AMH function in the testes remains to be elucidated (37).

In support of GWAS findings (26), we did not observe systematic associations between AMHR2 rs11170547 C $>\mathrm{T}$ and reproductive serum levels in boys.

\section{Females}

The negative association between $A M H$ rs $10407022 \mathrm{G}$ and estradiol levels in late adolescent girls was based on very few observations and may thus be a random finding. In addition, the here-employed estradiol assay is insensitive in ranges near the detection limit. We also did not time our blood sampling in girls who had experienced menarche to a specific cycle day, which may explain the large variation in many reproductive hormones, i.e. $\mathrm{LH}$, inhibin $\mathrm{B}$ and estradiol in this late pubertal group. Furthermore, due to the putative inhibitory effect on aromatase activity, we would expect the opposite effect; i.e. higher estradiol levels in homozygote minor alleles with reduced AMH function.

The positive association with estradiol observed in AMHR2 rs11170547 C>T heterozygotes seems more physiologically relevant. However, low levels of estradiol in the few homozygote minor alleles question this finding. In support of a true positive association is other data from healthy adult women, in whom minor allele carriers of AMH rs10407022 T>G and AMHR2 rs11170547 $\mathrm{C}>\mathrm{T}$ had higher serum levels of estradiol, which did not affect their numbers of antral follicles (23). These findings support in vitro data of $\mathrm{AMH}$-suppressing aromatase activity in granulosa cells $(38,39)$.

We found a statistically significant and positive effect of the $A M H$ SNP on circulating testosterone in the prepubertal girls. This was, however, not consistent across the alleles; i.e. testosterone was lower in the small homozygote group. We would expect that an impaired

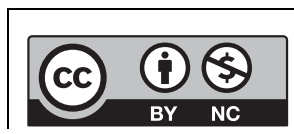

This work is licensed under a Creative Commons Attribution-NonCommercial 4.0 International License. 
AMH signaling increased the aromatase activity and thereby decreased the testosterone level. Additionally, in prepubertal girls, a major part of circulating testosterone is derived from the adrenal gland.

Our findings are also in line with studies of adult women, where the two investigated SNPs did not affect circulating AMH levels (23). In a cross-sectional study of healthy women, $A M H$ rs10407022 T>G affected age at menopause only when interaction with AMHR2 rs11170547 C>T was considered, however, the effect size was limited (25). Consequently, when serum levels of $\mathrm{AMH}$ are used to counsel individual women about their reproductive lifespan, genetic variation of AMH signaling does not seem to be relevant to account for.

We speculate if the striking gender difference regarding the selected $A M H \mathrm{SNP}$ in exon 1 could be explained by different splice variants expressed in the testes and ovaries. It is known that the testes primarily express the splice variant of the $A M H$ gene with exon 1 , which is not the case in the ovaries and pituritary gland, respectively (https://www.gtexportal.org/home/). Mamsen and coworkers (40) have shown that the levels of precursor molecules of AMH differ in the testes compared to the ovaries, which further points at gender difference in the genetic regulation of AMH levels.

\section{Strengths and limitations}

The children in this population-based cohort study are from ten schools in the affluent part of Copenhagen, and they may therefore not be fully representable for the entire background population. Girls were not examined according to their menstrual cycle. A major challenge for the interpretation of our data is the low minor allele frequency and thus low number of homozygotes in both sexes. Time interval from blood sampling to hormone assay analysis was independent from genotype. Thus, identified differences in hormone level between genotypes were not attributable to storage duration. Possible risk of blood sample damage resulting in low or false hormone level results is deemed highly unlikely, as repeated analysis of the same sample after re-freezing and thawing has produced similar hormone levels in our laboratory.

In addition to the main hypothesis of $\mathrm{AMH}$ polymorphisms affecting circulating AMH levels, we have tested a number of secondary associations with other hormone levels. Thus, there is a risk of type I error. We have therefore approached weak associations with critical interpretations.

$$
\text { http://www.endocrineconnections.org }
$$

In conclusion, genetic variation of AMH signaling was associated with circulating AMH levels in boys at specific stages of pubertal development. Further studies are necessary to elucidate whether low AMH in minor allele carriers of $A M H$ rs10407022 T>G could potentially reflect compromised adult testicular function.

\section{Supplementary data}

This is linked to the online version of the paper at https://doi.org/10.1530/ EC-17-0299.

\section{Declaration of interest}

The authors declare that there is no conflict of interest that could be perceived as prejudicing the impartiality of the research reported.

\section{Funding}

Danish Agency for Science, Technology and Innovation (09-067180); Danish Ministry of the Environment, CeHoS (MST-621-00065); Capital Region of Denmark (R129-A3966); Ministry of Higher Education and Science (DFF-1331-00113); The Innovation Fund Denmark (InnovationsFonden, 14-2013-4); The International Center for Research and Research Training in Endocrine Disrupting Effects of Male Reproduction and Child Health (EDMaRC).

\section{Author contribution statement}

I K G, A S B and C P H carried out analyses and drafted the article. M G M, $L A$ and C P H collected data. K A carried out genetic analyses, K M M and A J designed the study. All authors critically revised the manuscript and approved its final version.

\section{References}

1 Vigier B, Picard JY, Tran D, Legeai L \& Josso N. Production of anti-Müllerian hormone: another homology between sertoli and granulosa cells. Endocrinology 1984114 1315-1320. (https://doi. org/10.1210/endo-114-4-1315)

2 Tran D, Muesy-Dessole N \& Josso N. Anti-Müllerian hormone is a functional marker of foetal sertoli cells. Nature $1977269411-412$ (https://doi.org/10.1038/269411a0)

3 Cate RL, Mattaliano RJ, Hession C, Tizard R, Farber NM, Cheung A, Ninfa EG, Frey AZ, Gash DJ \& Chow EP. Isolation of the bovine and human genes for müllerian inhibiting substance and expression of the human gene in animal cells. Cell 198645 685-698. (https://doi. org/10.1016/0092-8674(86)90783-X)

4 Imbeaud S, Faure E, Lamarre I, Mattéi MG, di Clemente N, Tizard R, Carré-Eusèbe D, Belville C, Tragethon L, Tonkin C, et al. Insensitivity to anti-Müllerian hormone due to a mutation in the human antiMüllerian hormone receptor. Nature Genetics 199511 382-388. (https://doi.org/10.1038/ng1295-382)

5 Jost A. Hormonal factors in the sex differentiation of the mammalian foetus. Philosophical Transactions of the Royal Society of London. Series B, Biological Sciences 1970259 119-130. (https://doi. org/10.1098/rstb.1970.0052)

6 Rey RA \& Grinspon RP. Normal male sexual differentiation and aetiology of disorders of sex development. Best Practice and Research: Clinical Endocrinology and Metabolism 201125 221-238. (https://doi.org/10.1016/j.beem.2010.08.013)

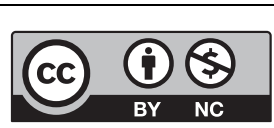

This work is licensed under a Creative Commons Attribution-NonCommercial 4.0 International License. 
7 Picard JY, Cate RL, Racine C \& Josso N. The persistent Müllerian duct syndrome: an update based upon a personal experience of 157 cases. Sexual Development 2017 109-125. (https://doi. org/10.1159/000475516)

8 Aksglaede L, Sørensen K, Boas M, Mouritsen A, Hagen CP, Jensen RB, Petersen JH, Linneberg A, Andersson AM, Main KM, et al. Changes in Anti-Müllerian Hormone (AMH) throughout the life span: a population-based study of 1027 healthy males from birth (cord blood) to the age of 69 years. Journal of Clinical Endocrinology and Metabolism 201095 5357-5364. (https://doi.org/10.1210/jc.2010-1207)

9 Chemes HE, Rey RA, Nistal M, Regadera J, Musse M, GonzálezPeramato P \& Serrano Á. Physiological androgen insensitivity of the fetal, neonatal, and early infantile testis is explained by the ontogeny of the androgen receptor expression in sertoli cells. Journal of Clinical Endocrinology and Metabolism 200893 4408-4412. (https://doi.org/10.1210/jc.2008-0915)

10 Lindhardt Johansen M, Hagen CP, Johannsen TH, Main KM, Picard JY, Jørgensen A, Rajpert-De Meyts E, Juul A \& Johansen ML. Anti-Müllerian hormone and its clinical use in pediatrics with special emphasis on disorders of sex development. International Journal of Endocrinology 20132013198698.

11 Andersen JM, Herning H, Witczak O \& Haugen TB. Anti-Müllerian hormone in seminal plasma and serum: association with sperm count and sperm motility. Human Reproduction 201631 1662-1667. (https://doi.org/10.1093/humrep/dew121)

12 Teixeira J, Maheswaran S, \& Donahoe PK. Müllerian inhibiting substance: an instructive developmental hormone with diagnostic and possible therapeutic applications. Endocrine Reviews 200122 657-674.

13 Al-Qahtani A, Muttukrishna S, Appasamy M, Johns J, Cranfield M, Visser JA, Themmen APN \& Groome NP. Development of a sensitive enzyme immunoassay for anti-Müllerian hormone and the evaluation of potential clinical applications in males and females. Clinical Endocrinology 200563 267-273. (https://doi.org/10.1111/ j.1365-2265.2005.02336.x)

14 Goulis DG, Iliadou PK, Tsametis C, Gerou S, Tarlatzis BC, Bontis IN \& Papadimas I. Serum anti-Müllerian hormone levels differentiate control from subfertile men but not men with different causes of subfertility. Gynecological Endocrinology 200824 158-160. (https://doi.org/10.1080/09513590701672314)

15 Durlinger ALL, Gruijters MJG, Kramer P, Karels B, Ingraham HA, Nachtigal MW, Uilenbroek JTJ, Grootegoed JA \& Themmen APN. Anti-Müllerian hormone inhibits initiation of primordial follicle growth in the mouse ovary. Endocrinology 2002143 1076-1084. (https://doi.org/10.1210/endo.143.3.8691)

16 Vigier B, Forest MG, Eychenne B, Bézard J, Garrigou O, Robel P \& Josso N. Anti-Müllerian hormone produces endocrine sex reversal of fetal ovaries. PNAS 198986 3684-3688. (https://doi.org/10.1073/ pnas.86.10.3684)

17 Grossman MP, Nakajima ST, Fallat ME \& Siow Y. Müllerian-inhibiting substance inhibits cytochrome p450 aromatase activity in human granulosa lutein cell culture. Fertility and Sterility 200889 1364-1370. (https://doi.org/10.1016/j.fertnstert.2007.03.066)

18 Yding Andersen C, Rosendahl M \& Byskov AG. Concentration of anti-Müllerian hormone and inhibin-b in relation to steroids and age in follicular fluid from small antral human follicles. Journal of Clinical Endocrinology and Metabolism 200893 2344-2349. (https://doi.org/10.1210/jc.2007-2342)

19 Hansen KR, Hodnett GM, Knowlton N \& Craig LB. Correlation of ovarian reserve tests with histologically determined primordial follicle number. Fertility and Sterility 201195 170-175. (https://doi.org/10.1016/j.fertnstert.2010.04.006)

20 Van Rooij IAJ, Den Tonkelaar I, Broekmans FJM, Looman CWN, Scheffer GJ, De Jong FH, Themmen APN \& Te Velde ER. AntiMüllerian hormone is a promising predictor for the occurrence of the menopausal transition. Menopause 200411 601-606. (https://doi.org/10.1097/01.GME.0000123642.76105.6E)
21 Hagen CP, Aksglaede L, Sørensen K, Mouritsen A, Andersson AM, Petersen JH, Main KM \& Juul A. Individual serum levels of antiMllerian hormone in healthy girls persist through childhood and adolescence: a longitudinal cohort study. Human Reproduction 201227 861-866. (https://doi.org/10.1093/humrep/der435)

22 Kevenaar ME, Laven JSE, Fong SL, Uitterlinden AG, de Jong FH, Themmen APN \& Visser JA. A functional anti-mullerian hormone gene polymorphism is associated with follicle number and androgen levels in polycystic ovary syndrome patients. Journal of Clinical Endocrinology and Metabolism 200893 1310-1316. (https://doi. org/10.1210/jc.2007-2205)

23 Kevenaar ME, Themmen APN, Laven JSE, Sonntag B, Fong SL, Uitterlinden AG, de Jong FH, Pols HAP, Simoni M \& Visser JA. AntiMüllerian hormone and anti-Müllerian hormone type II receptor polymorphisms are associated with follicular phase estradiol levels in normo-ovulatory women. Human Reproduction 200722 1547-1554. (https://doi.org/10.1093/humrep/dem036)

24 Yates A, Akanni W, Amode MR, Barrell D, Billis K, Carvalho-Silva D, Cummins C, Clapham P, Fitzgerald S, Gil L, et al. 2016. Ensembl 2016. Nucleic Acids Research 201644 D710-D716. (https://doi. org/10.1093/nar/gkv1157)

25 Braem MGM, Voorhuis M, van der Schouw YT, Peeters PHM, Schouten LJ, Eijkemans MJC, Broekmans FJ \& Onland-Moret NC. Interactions between genetic variants in aMH and AMHR2 may modify age at natural menopause. PLOS ONE 20138 8-11.

26 Perry JRB, McMahon G, Day FR, Ring SM, Nelson SM \& Lawlor DA. Genome-wide association study identifies common and lowfrequency variants at the $\mathrm{AMH}$ gene locus that strongly predict serum AMH levels in males. Human Molecular Genetics 201625 382-388. (https://doi.org/10.1093/hmg/ddv465)

27 Aksglaede L, Sørensen K, Petersen JH, Skakkebaek NE \& Juul A. Recent decline in age at breast development: the copenhagen puberty study. Pediatrics 2009123 e932-e939. (https://doi. org/10.1542/peds.2008-2491)

28 Sørensen K, Aksglaede L, Petersen JH \& Juul A. Recent changes in pubertal timing in healthy danish boys: associations with body mass index. Journal of Clinical Endocrinology and Metabolism 201095 263-270.

29 Hagen CP, Sørensen K, Aksglaede L, Mouritsen A, Mieritz MG, Tinggaard J, Wohlfart-Veje C, Petersen JH, Main KM, Rajpert-De Meyts E, et al. Pubertal onset in girls is strongly influenced by genetic variation affecting FSH action. Scientific Reports 201446412. (https://doi.org/10.1038/srep06412)

30 Tanner JM. Growth at Adolescence. Oxford, UK: Blackwell Scientific Publications, 1962.

31 Søeborg T, Frederiksen H, Fruekilde P, Johannsen TH, Juul A $\&$ Andersson AM. Serum concentrations of DHEA, DHEAS, $17 \alpha$-hydroxyprogesterone, $\delta 4$-androstenedione and testosterone in children determined by TurboFlow-LC-MS/MS. Clinica Chimica Acta 2013419 95-101.

32 Josso N, Rey RA \& Picard JY. Anti-Müllerian hormone: a valuable addition to the toolbox of the pediatric endocrinologist. International Journal of Endocrinology 20132013674105. (https://doi.org/10.1155/2013/674105)

33 Misra M, MacLaughlin DT, Donahoe PK \& Lee MM. Measurement of Mullerian inhibiting substance facilitates management of boys with microphallus and cryptorchidism. Journal of Clinical Endocrinology and Metabolism 200287 3598-3602. (https://doi.org/10.1210/ jcem.87.8.8742)

34 Aksglaede L, Christiansen P, Sørensen K, Boas M, Linneberg A, Main KM, Andersson AM, Skakkebaek NE \& Juul A. Serum concentrations of Anti-Müllerian Hormone (AMH) in 95 patients with Klinefelter syndrome with or without cryptorchidism. Acto Paediatrica 2011100 839-845. (https://doi.org/10.1111/j.16512227.2011.02148.x)

35 Kucera R, Ulcova-Gallova Z, Windrichova J, Losan P \& Topolcan O. Anti-Müllerian hormone in serum and seminal plasma in

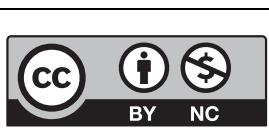


comparison with other male fertility parameters. Systems Biology in Reproductive Medicine 201662 223-226. (https://doi.org/10.3109/193 96368.2016.1161864)

36 Cimino I, Casoni F, Liu X, Messina A, Parkash J, Jamin SP, CatteauJonard S, Collier F, Baroncini M, Dewailly D, et al. Novel role for antiMüllerian hormone in the regulation of GnRH neuron excitability and hormone secretion. Nature Communications 2016710055. (https://doi.org/10.1038/ncomms10055)

37 Josso N \& di Clemente N. Transduction pathway of anti-Müllerian hormone, a sex-specific member of the TGF-beta family. Trends in Endocrinology and Metabolism 2003 14 91-97. (https://doi. org/10.1016/S1043-2760(03)00005-5)

38 Andersen CY \& Byskov AG. Estradiol and regulation of antiMüllerian hormone, inhibin-A, and inhibin-B secretion: analysis of small antral and preovulatory human follicles' fluid. Journal of Clinical Endocrinology and Metabolism $2006914064-4069$. (https://doi.org/10.1210/jc.2006-1066)

39 Chang HM, Klausen C \& Leung PCK. Antimüllerian hormone inhibits follicle-stimulating hormone-induced adenylyl cyclase activation, aromatase expression, and estradiol production in human granulosa-lutein cells. Fertility and Sterility 2013100585. e1-592.e1. (https://doi.org/10.1016/j.fertnstert. 2013.04.019)

40 Mamsen LS, Petersen TS, Jeppesen JV, Mollgård K, Grondahl ML, Larsen A, Ernst E, Oxvig C, Kumar A, Kalra B, et al. Proteolytic processing of anti-Müllerian hormone differs between human fetal testes and adult ovaries. Molecular Human Reproduction 201521 571-582. (https://doi.org/10.1093/molehr/gav024)

Received in final form 9 December 2017

Accepted 22 January 2018

Accepted Preprint published online 22 January 2018 http://www.endocrineconnections.org https://doi.org/10.1530/EC-17-0299
(C) 2018 The authors Published by Bioscientifica Ltd

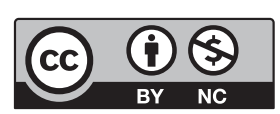

This work is licensed under a Creative Commons Attribution-NonCommercial 4.0 International License. 